Primljen / Received: 15.7.2013. Ispravljen / Corrected: 12.9.2013.

Prihvaćen / Accepted: 20.9.2013.

Dostupno online / Available online: 10.11.2013.

\section{Rutting resistance of waterproofing - asphalt pavement systems on bridges}

\section{Authors:}

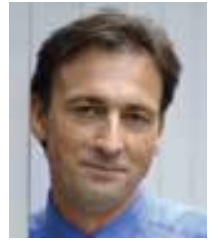

Miroslav Šimun, PhD. CE

Institute IGH d.d.

miroslav.simun@igh.hr

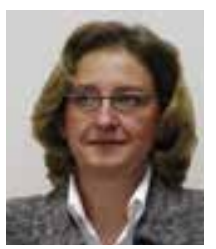

Prof. Tatjana Rukavina, PhD. CE

University of Zagreb

Faculty of Civil Engineering

rukavina@grad.hr

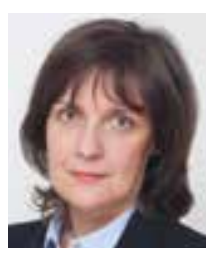

Assoc.Prof. Sanja Dimter, PhD. CE

University of J.J. Strossmayer in Osijek

Faculty of Civil Engineering

sdimter@gfos.hr

\section{Miroslav Šimun, Tatjana Rukavina, Sanja Dimter}

\section{Rutting resistance of waterproofing - asphalt pavement systems on bridges}

Application of traditional waterproofing systems with thin asphalt courses results in occurrence of plastic deformities on traffic areas of bridges, especially in the form of rutting. The investigations comprised the analysis of the existing systems in exploitation, laboratory testing and on site measurements of relevant properties of individual system elements, as well as the system as whole, which have an impact to the resistance to rutting. The achieved results were controlled and confirmed on the waterproofing - asphalt courses system executed during construction of the Odra viaduct on the A11 motorway.

Key words:
waterproofing of bridges, asphalt pavement, rutting, polymer modified bitumen, concrete deck

Miroslav Šimun, Tatjana Rukavina, Sanja Dimter

Prethodno priopćenje

\section{Otpornost na kolotraženje sustava hidroizolacija - asfaltni kolnik na mostovima}

Na voznim površinama mostova pri primjeni klasičnih sustava hidroizolacije s tankim asfaltnim slojevima učestalo se pojavljaju plastične deformacije, posebice one oblika kolotraga. U okviru istraživanja provedena je analiza postojećih sustava u eksploataciji, laboratorijska ispitivanja i terenska mjerenja relevantnih svojstava pojedinih elemenata sustava, kao i sustava u cjelini, koji utječu na otpornost pojave kolotraga. Dobiveni rezultati su provjereni i potvrdeni na primjenjenom sustavu hidroizolacija - asfaltni kolnik pri izgradnji vijadukta Odra na autocesti A11.

Ključne riječi:

hidroizolacija mostova, asfaltni kolnik, kolotraženje, polimerom modificirani bitumen, betonska ploča

Vorherige Mitteilung

Miroslav Šimun, Tatjana Rukavina, Sanja Dimter

\section{Spurrinnenbeständigkeit des Wasserabdichtungs - und Asphaltbelagsystems von Brücken}

Die Anwendung traditioneller Wasserabdichtungssysteme mit dünnen Asphaltschichten führt zum Auftreten plastischer Verformungen in Verkehrsbereichen von Brücken, insbesondere in der Form von Spurrinnen. Die Untersuchungen in dieser Arbeit umfassen Analysen bestehender Systeme in Betrieb, experimentelle Versuche und, sowohl für individuelle Systemelemente als auch für ganze Systeme, Messungen vor Ort der relevanten Eigenschaften, die Einfluss auf die Spurrinnenbeständigkeit haben. Die erhaltenen Resultate sind im Laufe der Erbauung des Odra Viadukts auf der Autobahn A11 anhand des entsprechenden Wasserabdichtungs- und Asphaltbelagsystems kontrolliert und bestätigt worden. 


\section{Introduction}

The serviceability level of an infrastructure facility/structure, viewed from the aspect of safety, driving comfort, and durability of driving surface, has to be considered through the quality of the asphalt pavement - waterproofing system. The sealing waterproofing layer has to be made of stable watertight materials placed in the prescribed manner, which includes an adequately developed base and high-quality protective and final pavement courses. Asphalt pavement courses on bridges serve as the driving surface and, during exploitation, they have to meet conditions for safe and comfortable driving. Traditional design solutions for waterproofing - asphalt systems call for utilisation of fine-grained asphalt mixtures, and tolerate relatively small deviations in course thickness. In the case of uneven and poor compaction level of courses placed on an extremely hard concrete or steel base, they exhibit low resistance to permanent pavement deformations in the form of rutting. Often the protective course has the function of a levelling course, and it is realized in either excessive or insufficient technological thicknesses. Details not specified in the design such as the waterproofing ends at expansion joints, concrete kerbs, and gullies, the absence of drainage canals, drainage basins, and soakaways that ensure goodquality drainage of water from pavement, are deficiencies that are detrimental to proper functioning of the waterproofing asphalt pavement systems. According to available data, average maximum summer temperatures on pavement surfaces reach up to $60^{\circ} \mathrm{C}$ in some parts of Croatia. At such extreme pavement temperatures on road structures $\left(60^{\circ} \mathrm{C}\right)$, which may last for several hours, the asphalt stiffness decreases significantly, and there is a great probability of plastic flow in the form of rutting; the standard testing of resistance to rutting at the temperature of $60^{\circ} \mathrm{C}$ shall be conducted for the purposes of this paper. Generally, properties of asphalt placed on structures are not defined separately, although experience clearly points to specific differences in the realization and use of pavement structures on structures (e.g. bridges), when compared to asphalt pavement structures on roads.

\section{Waterproofing - asphalt pavement system}

A wide range of waterproofing construction products, and many types of asphalt mixes with various binder properties, are currently available on the market. Several types of waterproofing are applied in Croatia in combination with asphalt courses. Sealing courses made of welded prefabricated bitumen strips with the epoxy resin base, and those made of the fine-grained (levelling) protective and final wearing course of rolled asphalt, are most often used. Due to variations in course thickness, physicomechanical properties of placed fine-grained asphalt mixtures are relatively low, which frequently results in the occurrence of defects, rutting in particular. In addition, an average total thickness of all courses usually amounts to approximately seven centimetres. Such a relatively thin flexible asphalt structure, lying on an extremely hard concrete or steel pavement slab exhibits, a low resistance to plastic deformities under the heavy truck traffic at high outside temperatures. The analyses of measured traffic surface roughness index (IRI) [1] established significantly higher roughness levels on asphalt pavements of road structures, in comparison to roughness levels registered at other parts of the road. An insufficient evenness of pavement on bridges is due to unevenness/roughness of deck slab surfaces, which cannot be smoothed down by realization of thin asphalt courses made of fine-grained asphalt mixtures characterized by low resistance to rutting. A traditional waterproofing - asphalt system presented in Figure 1 comprises the following:

- Primer made of epoxy resin or bitumen coating, which serves for development of the base surface (concrete or steel deck) in order to achieve a good adhesion between the sealing course and the underlying slab. In case of local depressions, the application of primer is preceded by levelling using epoxy mortar, i.e. by mechanical removal of bumps from the bearing slab surface.

- Sealing course made of bitumen strips or polyurethane membranes, whose role is to ensure basic waterproofing functions. In this respect, it prevents liquid medium from penetrating through asphalt courses and reaching the surface of concrete or steel elements of the deck slab.

- Protective (levelling) course made of rolled asphalt (asphalt concrete, AC, or split mastic asphalt, SMA) or mastic asphalt (MA), which has a protective role, i.e. it has to be placed in such a way to prevent mechanical or temperature defects of the sealing course, or any other occurrence that might affect watertightness. This course may serve as both the load-bearing course and the binding course. An additional course may be also be included in the system, in order to further improve roughness and resistance to rutting.

- Wearing course made of rolled asphalt type AC or SMA, which serves as the driving surface of the pavement and has to meet requirements relating to roughness (IRI), skid resistance (SRT), and texture, which are important for ensuring safe and comfortable driving.

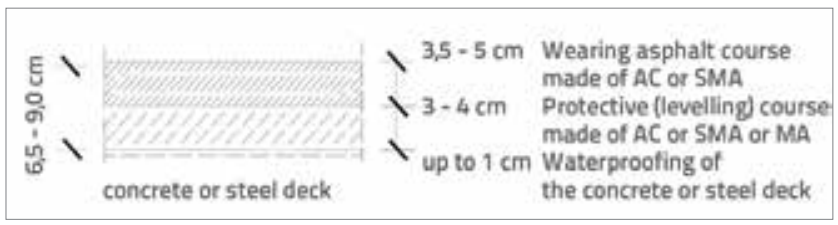

Figure 1. Cross section of a traditional waterproofing - asphalt courses system for structures

\subsection{Current investigations}

Strineka [2] studied the impact of bitumen mortar composition on the deformability of asphalt. It was established that the speed of rutting linearly decreases with the increase of the volume part of filler in bitumen mortar. The application of the determined dependence of the rutting depth and rutting rate 
on the composition of asphalt specimens, enables definition of optimum asphalt mixtures, taking into consideration other asphalt properties required in specific cases. The polymer (elastomer or plastomer) modified bitumen, characterised by higher equiviscous temperature during placing, is utilised in order to improve asphalt pavement properties for increasing resistance to permanent deformity in the form of rutting. The use of asphalt mixtures with addition of bitumen, which reduces temperature during production and placing, contributes to lowering of the sealing course defect risk and, furthermore, it reduces environmental pollution in compliance with the Kyoto protocol [3]. The resistance of waterproofing - asphalt pavement systems to plastic deformities on concrete bridges was studied in the framework of the EP1 project (Standfester Gesamutaufbau, Prufung und Bewertung). A series of model studies based on physical observations resulted in development of specific models for defining compressive and tensile stresses in asphalt courses: Erkens [4], Bosch [5], Medani et al. [6], Aireyet et al. [7], Jansen [8]. The definition of individual properties of asphalt materials (stress, rigidity, cracks, plasticity) as input data enables development of a combined numerical model of asphalt behaviour. Bild [9] investigated durability as a criterion for designing asphalt pavements on orthotropic steel deck bridges.

\subsection{Property of resistance to rutting}

Ruts are manifested in asphalt pavements as longitudinal depressions in the trajectory of wheels, with small elevations at edges. They occur due to progressive deformities during application of repeated load produced by wheels of the vehicle. Asphalt rutting may be caused by plastic flow and consolidation. The principle cause of asphalt rutting is plastic flow occurring due to shear deformation in asphalt mixture. A reduced shear resistance may be caused by inadequate quantity of bitumen in the mixture, inadequate grain size distribution, and by deformities resulting from humidity in the mixture, or by a bad stone skeleton. The consolidation is a continued compaction of pavement due to traffic load. Because of inadequate compaction, the proportion of voids in the placed asphalt is higher than specified. Movement of vehicles along similar trajectories causes additional compaction in the wheel zone. The contribution of rutting caused by additional compaction of material in the wheels trajectory zone in the overall amount of rutting is relatively small. The rutting is a direct indicator of asphalt behaviour under load, as related to temperature conditions during pavement use. Values of tested parameters (total rut depth, $\mathrm{RD}$, relative rut depth, $\mathrm{PRD}$, and the rate of rut development, WTS) define properties of actual asphalt specimens with regard to requirements for asphalt courses systems with waterproofing applied on the load-bearing structure [10]. The progression of rutting affecting relatively thin asphalt courses executed on top of a rigid concrete or steel bridge deck is influenced by heavy vehicles, which cause additional dynamic loads due to unevenness of the traffic surface, especially in the zone of expansion joints. The waterproofing - asphalt pavement system is exposed to the effects of climatic changes and traffic loads, and its purpose is to meet exploitation conditions over many years. Numerous and highly varied defects occur during the service life of transport facilities.

The causes of defects occurring in the waterproofing - asphalt pavement systems are the following:

- Internal factors, i.e. physicomechanical properties of materials and courses used in the system;

- External factors are climatic effects during service life (temperature and humidity), load, traffic density, and speed;

- Conditions during construction of the system, i.e. asphalt placing temperature, humidity of air and humidity at the base, and asphalt compaction energy and procedure.

The principal cause of rutting in waterproofing - asphalt pavement systems, which occurs after increasingly shorter exploitation times, is certainly the increase in number of trucks and the increase in axial load values, as registered over the past fifteen years [11].

\section{Testing resistance to rutting}

The laboratory testing was conducted according to standard methods in order to determine behaviour of elements of the waterproofing - asphalt pavement system, and behaviour of the system as a whole, and also to establish the theses for a new approach. The first part of investigations comprised optimisation of properties of the asphalt concrete specimen, namely the voids content and the depth and rate of rutting development; the second part of investigations was aimed at determining rutting resistance of the waterproofing - asphalt pavement system.

According to the testing method compliant with the standard HRN EN 12697-22 [12], the wheel load on asphalt surface amounts to $700 \mathrm{~N}$, the wheel trajectory length for rutting measurements amounts to $230 \mathrm{~mm}$, and the frequency of wheel load application is 26.5 passes/minute. The testing temperature during the rutting cycle, as well as the temperature of the previously heated testing specimen, amounts to $60^{\circ} \mathrm{C}$; and the complete rutting procedure comprises 20,000 passes of the testing wheel. The testing of permanent deformation according to the rutting procedure is preceded by determination of the thickness, density, and voids content of the tested specimen. Once the specimen is fixed to the testing mould, the specimen is conditioned in the thermal chamber of the rutting device, and the mould containing the specimen is placed onto the moving testing table. The testing starts by adjusting parameters of the test cycle monitoring programme and by setting the device to perform the rutting procedure through repeated passes of the testing wheel. Upon completion of the testing $(20,000$ wheel passes $-10,000$ cycles), the maximum rut depth $\left(R D_{20000}\right)$ is read from the rutting curve, and the rutting speed $\left(W T S_{A I R}\right)$ and relative maximum rut depth $\left(P R D_{A I R}\right)$ values are calculated using the following equations (1) and (2):

$$
\begin{aligned}
& W T S_{A I R}=\frac{\left(R D_{20000}-R D_{1001}\right.}{5} \\
& P R D_{A I R}=\frac{R D_{20000}}{h}
\end{aligned}
$$


where:

WTS $_{\text {AIR }}$ - is the speed of rutting, [mm/1000 cycles]

$R D_{20000}$ - is the rut depth (after 20,000 passages), [mm]

$R D_{10000}$ - is the rut depth (after 10,000 passages) , [mm]

$h \quad-$ is the height (thickness) of tested sample, [mm]

$P R D_{\text {ZRAK }}$ - is the relative maximum rut depth, [\%]

\subsection{Optimisation of asphalt sample properties}

After weighing the input components ("šumber" stone dust, "kruškovec" stone skeleton sub-fraction, and bitumen), the hot asphalt mixture type AC 11 was homogenised in laboratory mixer (Figure 2) and asphalt courses were made in rutting moulds by means of a roller compactor (Figure 3). Asphalt specimens placed by roller compactor into steel moulds measuring $305 \times 305 \times 50 \mathrm{~mm}$ were tested for permanent deformation according to the rutting method, in a small-size device (Figure 4) using the procedure B (in air). Marshall testing specimens were prepared separately from the same mixture and their bulk density was determined. The apparent density was determined using the Pycnometer method. The voids content in a test specimen was calculated according to equation (3). The soluble bitumen content was determined by extracting the asphalt mixture dissolved in trichloroethylene by means of the asphalt analyser, and the grain size distribution was determined. The standard paving bitumen type BIT 50/70, and the polymer modified bitumen type PmB 45/80-65, were used as binders of stone material contained in the asphalt mixture.

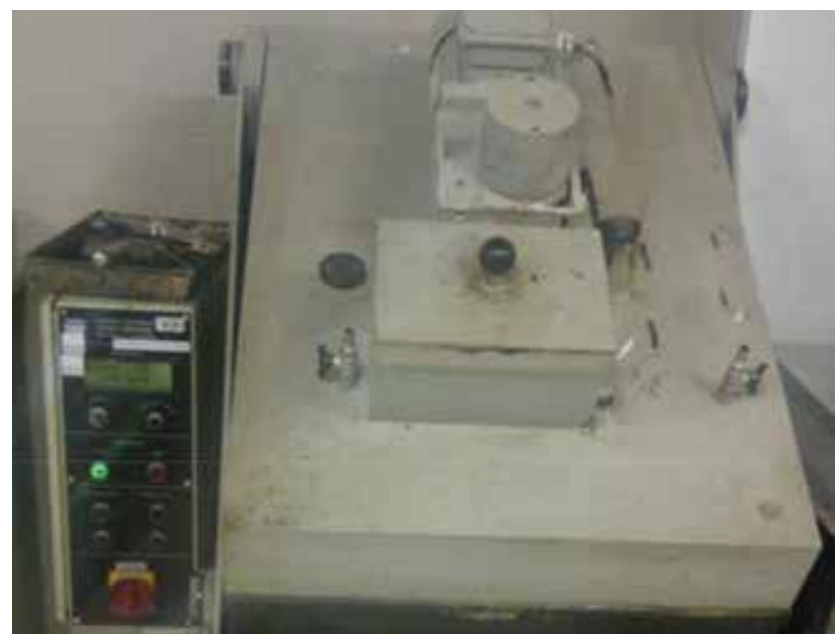

Figure 2. Laboratory asphalt mixer

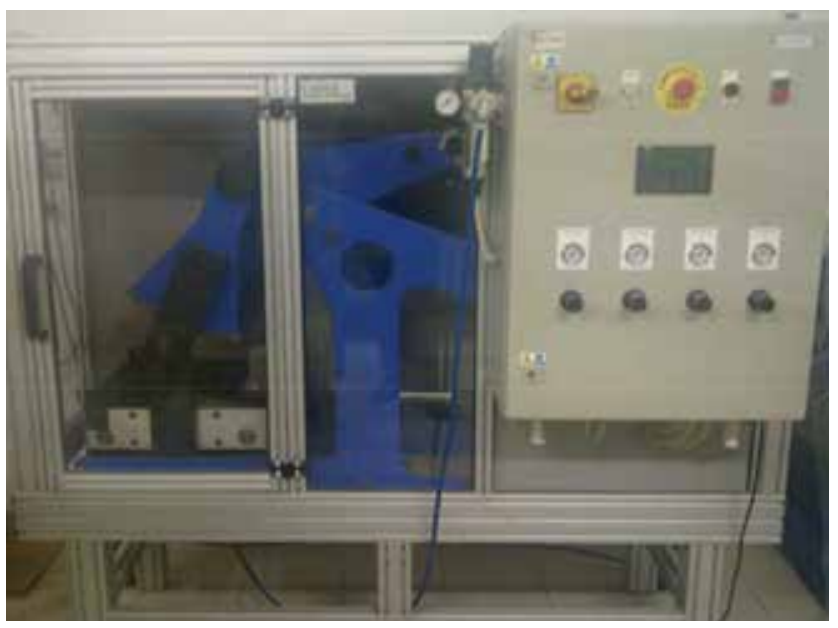

Figure 3. Roller compactor for compacting asphalt course in the mould

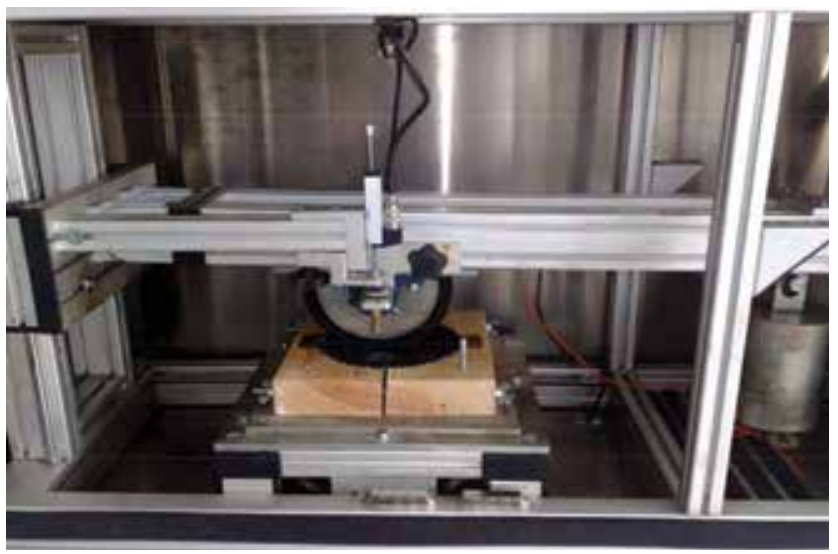

Fig. 4. "Wheel Tracker" rutting device

The bulk density of asphalt specimens $\left(\rho_{\mathrm{AU}}\right)$ and asphalt mixture density $\left(\rho_{\mathrm{AM}}\right)$ values are needed for calculating the voids content $C_{\check{S} / A \cup}$ of the asphalt specimen, in compliance with the standard HRN EN 12697-8 [13]:

$C_{\check{S} / A U}=\left(1-\frac{\rho_{A U}}{\rho_{A M}}\right) \cdot 100$

The composition of the first asphalt mixture (AM1) was characterised by a higher content of filler $(10,7 \%$ ) and a low content of bitumen $(3,6 \%$ ), and so a high voids content was registered $(8,2 \%)$. Although a good resistance to rutting was achieved, the mixture was still too stiff. For that reason, another

Table 1. Composition of asphalt mixtures and properties of relevant asphalt specimens and courses

\begin{tabular}{|c|c|c|c|c|c|c|c|c|}
\hline $\begin{array}{l}\text { Composition and } \\
\text { properties } \\
\text { Asphalt mixture }\end{array}$ & $\begin{array}{l}\% \mathrm{mas}_{\mathrm{P} / \mathrm{KM}} \\
{[\%(\mathrm{~m} / \mathrm{m})]}\end{array}$ & $\begin{array}{l}\% \mathrm{mas}_{\mathrm{B} / \mathrm{AM}} \\
{[\%(\mathrm{~m} / \mathrm{m})]}\end{array}$ & $\begin{array}{c}\rho_{\mathrm{AU}} \\
{\left[\mathrm{g} / \mathrm{cm}^{3}\right]}\end{array}$ & $\begin{array}{c}\rho_{\mathrm{AM}} \\
{\left[\mathrm{g} / \mathrm{cm}^{3}\right]}\end{array}$ & $\begin{array}{c}C_{\tilde{S} / A U} \\
{[\%(\mathrm{~V} / \mathrm{V})]}\end{array}$ & $\begin{array}{c}\mathrm{RD}_{20000} \\
{[\mathrm{~mm}]}\end{array}$ & $\begin{array}{c}\mathrm{PRD}_{20000} \\
-[\%]\end{array}$ & $\begin{array}{c}\text { WTS }_{\text {ZRAK }} \\
{\left[\mathrm{mm} / 10^{3} \mathrm{C}\right]}\end{array}$ \\
\hline AM1 & 10,7 & 3,6 & 2429 & 2648 & 8,2 & 2,2 & 4,3 & 0,07 \\
\hline $\mathrm{AM} 2 / 1$ & 9,4 & 7,0 & 2455 & 2504 & 2,0 & 8,6 & 17,2 & 0,13 \\
\hline $\mathrm{AM} 2 / 2$ & 9,0 & 5,1 & 2464 & 2593 & 5,0 & 2,5 & 4,9 & 0,07 \\
\hline АМЗ & 8,2 & 5,1 & 2444 & 2581 & 5,3 & 2,3 & 4,6 & 0,06 \\
\hline
\end{tabular}


asphalt mixture of modified composition (AM2) was prepared. Two asphalt mixtures with the same rock skeleton were mixed: the first one $(A M 2 / 1)$ with an increased content of bitumen $(7,0 \%)$, and the second one $(A M 2 / 2)$ with a regular content of bitumen $(5,1 \%)$. The test specimen made of the mixture AM2/1 showed a low voids content $(2,0 \%)$, while the specimen made of the mixture $A M 2 / 2$ showed an appropriate voids content $(5,0 \%)$. It was determined that the asphalt mixture $A M 2 / 1$ had a poor resistance to rutting due to the high bitumen content ( $28 \%$ higher $\mathrm{RD}$, and $27 \%$ higher PRD), while the asphalt mixture $A M 2 / 2$ was resistant to rutting. In both asphalt mixtures, the filler content was higher than could be expected for this type of asphalt concrete. The production of an optimum asphalt mixture type AC 11 (AM3) was attempted based on the collected data, with the filler content amounting to $8,2 \%$ and the bitumen content amounting to $5.1 \%$; an appropriate voids content was achieved $(5,3 \%)$, and the determined rut depths met requirements $(\mathrm{RD}=$ $2,3 \mathrm{~mm} ; \mathrm{PRD}=4,6 \%$, which also applies to the deformation rate (WTS $=0,06 \mathrm{~mm} / 10^{3}$ cycles).

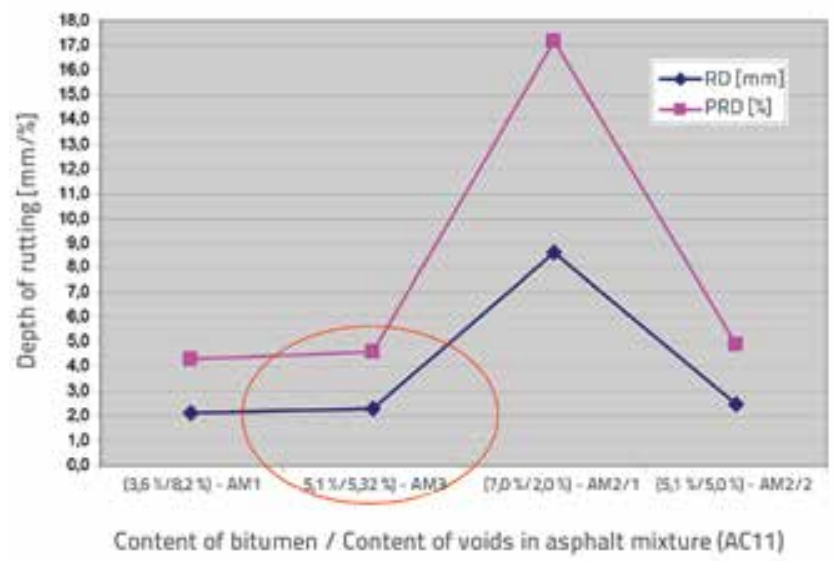

Figure 5. Asphalt course rutting depending on the content of bitumen and voids in asphalt mixture
The composition and properties of asphalt mixtures (AM) type AC (asphalt concrete) are presented in Table 1. Physicomechanical properties were determined on the corresponding Marshall asphalt specimen, while rutting resistance values were determined on the test specimen of asphalt formed in the mould.

Rutting depth variations ( $R D=$ maximum rutting depth, and $\mathrm{PRD}=$ relative maximum rutting depth) in asphalt courses, depending on bitumen content in asphalt mixture, and voids content in the compacted course, are graphically presented in Figure 5. An optimum asphalt mixture type AC 11 (AM3), with an adequate standard grading, contained $5,1 \%$ of bitumen and $5,3 \%$ of voids.

\subsection{Resistance of the system to rutting}

Once the rutting resistance of the optimised asphalt mixture AM3 was confirmed, alternative solutions of waterproofing - asphalt systems were developed in order to conduct the rutting resistance testing. The quartz-sand treated epoxy resin primer was applied to concrete slabs of required surface strength and texture ( $38 \mathrm{~mm}$ in thickness). The testing mould measured $305 \times 305 \mathrm{~mm}$ in plan. After verification of required properties, three types of waterproofing layers were applied onto the primer:

- polyurethane/bitumen elastic membrane on two alternative specimens $(P)$,

- single-layer bitumen plastomer strip on four alternative specimens $(\mathrm{HI})$, and

- double-layer bitumen plastomer strip on one alternative specimen (HII).

Asphalt course/courses of different thicknesses (28-54 $\mathrm{mm})$, with paving bitumen BIT 50/70 and polymer modified bitumen PmB 45/80-65, were laid on concrete slabs in testing

Table 2. Values of rutting parameters for the waterproofing - asphalt pavement system

\begin{tabular}{|c|c|c|c|c|c|c|c|c|}
\hline $\begin{array}{l}\text { Desig- } \\
\text { nation }\end{array}$ & $\begin{array}{l}\text { Thickness } \\
\text { of system } \\
\text { courses } \\
\text { [mm] }\end{array}$ & Bitumen & $\begin{array}{c}\text { Waterproofing } \\
\text { type }\end{array}$ & $\begin{array}{l}\text { Course } \\
\text { compact } \\
\min 98[\%]\end{array}$ & $\begin{array}{l}\text { Voids } \\
\text { content in } \\
\text { the course } \\
3,5-8[\%]\end{array}$ & $\begin{array}{l}\text { Rut depth } \\
\mathrm{RD}_{20000} \\
\max 3[\mathrm{~mm}]\end{array}$ & $\begin{array}{l}\text { Relative } \\
\text { depth } \\
\mathrm{PRD}_{20000} \\
\max 7[\%]\end{array}$ & $\begin{array}{c}\text { Formation speed } \\
\text { WTS } \\
\text { max } 0,07 \\
\text { [mm } / 10^{3} \text { cycles] }\end{array}$ \\
\hline WVI & $35(\mathrm{BIT})+2(\mathrm{P})$ & BIT 50/70 & polyurethane & 98,5 & 6,4 & 7,6 & 10,1 & 0,25 \\
\hline WVII & $30+30(\mathrm{BIT})+2(\mathrm{P})$ & BIT 50/70 & polyurethane & 101,1 & 4,0 & 3,6 & 3,6 & 0,11 \\
\hline WVIII & $52(\mathrm{BIT})+10(\mathrm{HII})$ & BIT 50/70 & $\begin{array}{l}\text { two bitumen } \\
\text { strips }\end{array}$ & 102,2 & 3,3 & 5,2 & 5,2 & 0,22 \\
\hline WIX & $28(\mathrm{BIT})+9(\mathrm{HI})$ & BIT 50/70 & one bitumen strip & - & 5,4 & 4,2 & 5,6 & 0,16 \\
\hline$w X$ & $53(\mathrm{BIT})+9(\mathrm{HI})$ & BIT 50/70 & one bitumen strip & - & 5,4 & 4,9 & 4,9 & 0,16 \\
\hline WXI & 29(PmB)+8(HI) & $\begin{array}{c}\text { PmB } \\
45 / 80-65\end{array}$ & one bitumen strip & - & 4,7 & 12,0 & 16,0 & 0,73 \\
\hline WXII & $54(\mathrm{PmB})+8(\mathrm{HI})$ & $\begin{array}{c}\text { PmB } \\
45 / 80-65\end{array}$ & one bitumen strip & - & 4,7 & 2,6 & 2,6 & 0,07 \\
\hline
\end{tabular}


moulds. Seven system types (WVI-WXII) were prepared with an optimum asphalt mixture (AM3), and the rutting resistance was tested using the Wheel Tracker device.

Rutting parameters (RD/PRD/WTS) for seven different types of waterproofing - asphalt course systems for bridges, with the determined properties of asphalt courses, are presented in Table 2. The determined rutting resistance values are satisfactory for one system only (WXII): $54 \mathrm{~mm}$ of asphalt with the polymer bitumen on $8 \mathrm{~mm}$ of the bitumen strip waterproofing placed in a single layer. The lowest rutting resistance was registered at the system (WXI): $29 \mathrm{~mm}$ of asphalt with the polymer bitumen on $8 \mathrm{~mm}$ of the single-layer bitumen strip waterproofing. The obtained results point to a high significance of technological thickness of asphalt courses. The asphalt is placed at the equiviscous temperature of bitumen (if $\mathrm{PmB}$ is used as binder, the temperature is even higher), and the penetration of bitumen mortar from the waterproofing occurs at the asphalt placing temperature. In case of fine-grained asphalt courses placed in the thicknesses of less than the minimum technological thickness (WXI) a significant filling of stone skeleton with bitumen mortar occurs during the placing, which results in poor resistance to rutting.

Rutting depth parameters (RD/PRD) for seven different types of waterproofing - asphalt pavement systems on the concrete deck are presented in Figure 6. High oscillations and high rutting depth values can clearly be seen.

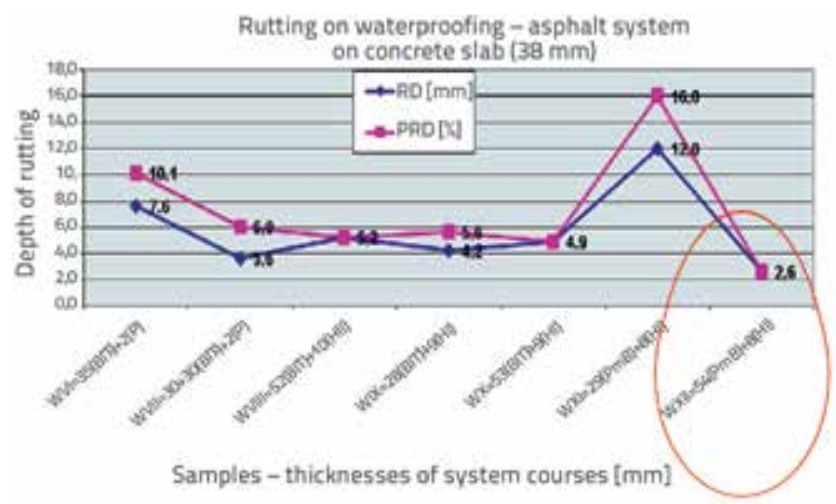

Figure 6. Graphical presentation of rutting depth for different alternatives of waterproofing - asphalt systems

Three types of specimens taken from the plant produced asphalt mixture, and sampled during placement of asphalt pavement courses at the Odra Viaduct on the Zagreb - Sisak A11 Motorway, were compacted in laboratory:

- protective asphalt course (AC-ZSH-L 16) $50 \mathrm{~mm}$ in thickness;

- wearing asphalt course (SMA 16) $50 \mathrm{~mm}$ in thickness, and

- protective asphalt course (AC-ZSH 16) and wearing asphalt course (SMA 16) $100 \mathrm{~mm}$ in thickness (50+50).

The following testing parameters were confirmed during determination of rutting resistance on the protective waterproofing course, type asphalt concrete AC-ZSH 16, placed in $305 \times 305 \times 50$ mould by roller compactor, using the rutting method on the protective course (AC-ZSH-L): the total rut depth $\mathrm{RD}=3,5 \mathrm{~mm} /$ relative rut depth $\mathrm{PRD}=7$ $\%$ / deformation rate WTS $=0,07 \mathrm{~mm} / 10^{3}$ cycles. Rutting parameters PRD and WTS meet the required conditions for the protective asphalt waterproofing course ( $\mathrm{AC}-\mathrm{ZSH}-\mathrm{L}$ ); however, they reach the very limit of the allowed maximum values as the paving bitumen BIT 50/70 was used as binder. The asphalt mixture of the wearing asphalt course, type split mastic asphalt (SMA), showed an extremely good rutting resistance. The split mastic asphalt has a good skeleton structure (discontinued grain size distribution) and the polymer modified bitumen was used. The rutting resistance of a two-layered specimen, which is a combination of the protective waterproofing course and wearing course, as in the pavement system ( $\mathrm{AC}-\mathrm{ZSH}+\mathrm{SMA})$, is identical to the rutting resistance of the specimen containing the wearing course SMA 16 only, which confirms that the rutting testing method using a small-size device and the procedure $B$ in air actually produces the most accurate results on asphalt courses of about $50 \mathrm{~mm}$ in thickness.

The system consisting of the sealing waterproofing course and the protective asphalt concrete course (AC-ZSH-G), sampled on the construction site (Figure 7) at three points $(\phi=200 \mathrm{~mm})$, was tested for rutting resistance in the laboratory. The rutting parameters for the pavement specimen are not compliant with requirements: $\mathrm{PRD}=10,2$ $\%$ (requirement $\leq 7 \%$ ) / WTS $=0,21$ (requirement $\leq 0,07$ ), paving bitumen BIT 50/70. A drop in rutting resistance was established when compared to the specimen prepared in laboratory (AC-ZSH-L).

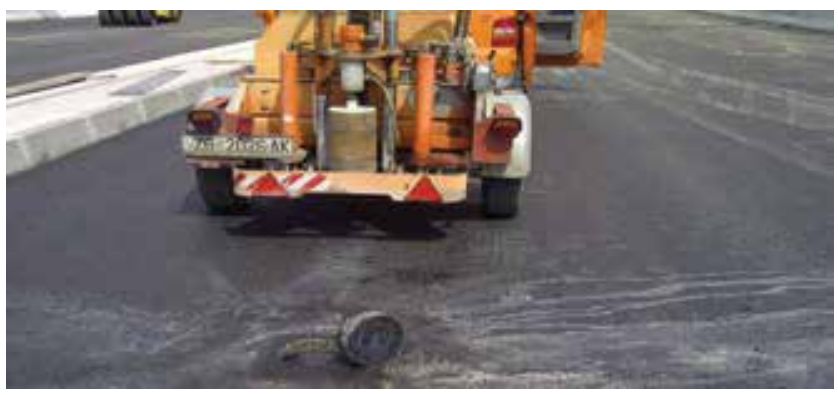

Figure 7. Sample taken at the Odra Viaduct from the completed waterproofing - asphalt system

Rutting parameters with appropriate compositions and physicomechanical properties are presented in Table 3 for samples:

- of the produced mixture of the protective (AC-ZSH16-L) and wearing (SMA16) courses, and

- of the two-layered protective and wearing course combination ( $\mathrm{AC}-\mathrm{ZSH}+\mathrm{SMA}$ ) and of the protective and sealing course of the system ( $A C-\mathrm{ZSH} 16-\mathrm{G}$ ) sampled from the completed viaduct pavement. 
Table 3. Composition and properties of asphalt mixtures with asphalt-course rutting parameters

\begin{tabular}{|c|c|c|c|c|c|c|c|c|}
\hline $\begin{array}{l}\text { Rutting } \\
\text { parameters } \\
\text { Asphalt } \\
\text { mixtures }\end{array}$ & $\begin{array}{l}\% \mathrm{mas}_{\mathrm{P} / \mathrm{KM}} \\
{[\%(\mathrm{~m} / \mathrm{m})]}\end{array}$ & $\begin{array}{l}\% \mathrm{mas}_{\mathrm{B} / \mathrm{AM}} \\
{[\%(\mathrm{~m} / \mathrm{m})]}\end{array}$ & $\begin{array}{c}\rho_{\mathrm{AU}} \\
{\left[\mathrm{g} / \mathrm{cm}^{3}\right]}\end{array}$ & $\begin{array}{c}\rho_{A} \\
{\left[\mathrm{~g} / \mathrm{cm}^{3}\right]}\end{array}$ & $\begin{array}{c}C_{\check{S} / A U} \\
4-9[\%(V / V)]\end{array}$ & $\begin{array}{l}\mathrm{RD}_{20000} \\
{[\mathrm{~mm}]}\end{array}$ & $\begin{array}{l}\mathrm{PRD}_{20000} \\
\max 7[\%]\end{array}$ & $\begin{array}{c}\text { WTS }_{\text {AIR }} \\
\max 0,07 \\
{\left[\mathrm{~mm} / 10^{3} \text { cycles] }\right.}\end{array}$ \\
\hline AC-ZSH16-L & 6,0 & 4,0 & 2500 & 2656 & 5,9 & 3,5 & 7,0 & 0,07 \\
\hline AC-ZSH16-G & 7,0 & 4,6 & 2502 & 2626 & 4,7 & 5,1 & 10,2 & 0,21 \\
\hline SMA16 & 10,0 & 5,0 & 2468 & 2583 & $(4,5)$ & 1,6 & 3,2 & 0,02 \\
\hline$A C-Z S H+S M A$ & - & - & - & - & - & 1,6 & 1,6 & 0,03 \\
\hline
\end{tabular}

The asphalt course composition was checked in order to confirm the reasons behind the drop in rutting resistance. The density of asphalt mixture dissolved in trichloroethylene was determined by pycnometer method. The soluble bitumen content was determined on the samples of protective asphalt waterproofing courses, and the grain size distribution was analyzed in order to determine the filler content. Furthermore, additional composition testing results confirm penetration of bitumen from the sealing course into the protective course of the waterproofing - asphalt pavement system; the determined content amounted to $\%$ mas ${ }_{B / A S}=4,6 \%$, while the content prior to placing amounted to $\%$ mas ${ }_{B / A M}=4,0 \%$. The smaller voids content of the in-place protective course $\left(C_{\check{S} / \mathrm{AS}}=4,7 \%\right)$, as compared to the Marshall sample $\left(C_{\check{s} / A U}=5,9 \%\right)$, confirmed the penetration of bitumen mortar and a drop in the resistance to rutting, due to the filling of voids during the asphalt placing process.

\section{Conclusion}

A detailed analysis of standard waterproofing - asphalt pavement systems, realized with different types of primers, protective (levelling) courses, and wearing courses, is conducted in the scope of investigations. The systems placed on eleven structures (bridges, viaducts, and underpasses) are analysed from the aspect of occurrence of defects that affect the inservice behaviour of such structures. It was established that permanent (plastic) deformations of pavements, i.e. rutting deformations, are the most common asphalt-pavement defects on bridges, and that they are significantly more pronounced when compared to similar defects registered on the road route, i.e. in front of and after the structure/bridge.

Results of this investigation point to the conclusion that the resistance to rutting can be increased by the factor of $\geq 1,5$ if the binder with the polymer modified bitumen is applied. Assumptions were made by testing resistance to permanent deformation, i.e. rutting resistance, of different types of waterproofing - asphalt course systems prepared in laboratory, and these assumptions were subsequently checked by in situ testing.
Values above the prescribed maximum levels were determined on samples taken from the in-place waterproofing - protective rolled asphalt course system (Odra Viaduct), using the same rutting resistance testing method. This testing confirmed the thesis formulated in the laboratory, according to which the composition and properties of the protective asphalt course change during placement of this course on the sealing course made of bitumen strips. The testing of the asphalt concrete $A C$ $\mathrm{ZSH} 16$ using the core drilled from the in-place pavement confirmed the gradation of the stone skeleton and the increase of filler and, in this respect, a higher bitumen content and lower voids content were determined, when compared to the asphalt mixture sampled prior to the protective rolled asphalt course placing. The determined values indicate that the bitumen component of the sealing course, which is highly sensitive to temperature, penetrates from the sealing course into the protective course during placement of the hot rolled asphalt course, which causes changes of physicomechanical properties of asphalt, i.e. a decrease in the resistance of pavement to plastic deformations.

This investigation has defined the need for application of a new approach to the waterproofing - asphalt pavement systems on bridges, which includes selection of an adequate type of bitumen and asphalt mixture, taking into consideration allowed oscillations in the technological thickness of courses. The maximum size of grains in stone skeleton, and the number of asphalt courses within the system, are related to geometrical deviations of the grade line of the load-bearing deck slabs of structures. The design of asphalt mixtures with a more open grain size distribution, and the utilisation of the discontinuous grading, results in better resistance to rutting of the waterproofing asphalt course pavement systems. In the scope of further investigations on the waterproofing - asphalt pavement systems on bridges, it would be highly beneficial to investigate the use of asphalt mixtures with bitumen additives that would lower the asphalt temperature during the asphalt production and placing. 


\section{REFERENCES}

[1] Šimun, M., Rukavina, T.: Kriteriji uzdužne ravnosti vozne površine asfaltnih kolnika, Građevinar61 (2009) 12, 1143-1152.

[2] Strineka, A.: "Utjecaj sastava bitumenskog morta na deformabilnost asfalta", disertacija, Fakultet kemijskog inženjerstva i tehnologije, Zagreb (2010).

[3] Henigman, S., Žmavc, J.: 2006. Ljubljana "Asfalt", Združenje asfalterjev Slovenije, ISBN 961- 90448-6-X

[4] Erkens, S.M.J.G.: "Asphalt Concrete Response (ACRe), Determination, Modelling and Prediction" PhD Thesis, Delft University of Technology, The Netherlands, 2002.

[5] Bosch, A.: Material Characterisation of Mastic Asphalt Surfacings on Orthotropic Steel Bridges, MSc Thesis, Delft University of Technology, The Netherlands, 2001.

[6] Medani, T.O., Scarpas, A., Kolstein, M.H., Bosch, A., Huurman M., Molenaar A.A.A.: Estimation of the ACRe Material Model Parameters of Mastic Asphalt for Orthotropic Steel Deck Bridges, CROW 2002, Ede, The Netherlands, 2002.

[7] Airey, G.D., Collop, A.C., Dunhill, S.T.: A Constitutive Material Modelling Methodology for Asphalt Mixtures, ISAP 2002 Copenhagen, Denmark, 2002.
[8] Jansen, P.M.: Characterising EME, Enrobé á Modele Elevé, MSc Thesis, Delft University of Technology, The Netherlands, 2002.

[9] Bild, S.: Durability design criteria for bituminous pavement on orthotropic steel bridge decks, Canadian Journal of Civil Engineering, 14:(1): 41-48 (1987) 10.1139//87-006 NRC Canada

[10] Jian - Shiuh Chen, Min - Chin Liao, Ming - Shen Shiah: Asphalt Modified by Styrene - Butadiene Triblock Copolymer, Morfology and Model, J. Mat. In Civ. Engrg., Vol. 14, Issue 3, pp. $224-229$.

[11] Medani, T.O.: Design Principles of Surfacings on Orthotropic Steel Bridge Decks, Ph D Dissertation, Delft University of Technology, The Netherland 2006.

[12] HRN EN 12697-22 Bitumenske mješavine - Ispitne metode za asfalt proizveden vrućim postupkom - 22 dio: Kolotraženje

[13] HRN EN 12697-8:2003 Bitumenske mješavine - Ispitne metode za asfalt proizveden vrućim postupkom - 8. dio: Određivanje šupljina u asfaltnim uzorcima 